\title{
The Investigation of Builders and Building Supervisors' Responsibility in Iran Law
}

\author{
Marjan Hossein Zadeh $^{1}$ \& Abdolmohammad Afrough ${ }^{2}$ \\ ${ }^{1}$ Department of Private Law, Boushehr Branch, Islamic Azad University, Boushehr, Iran \\ ${ }^{2}$ Department of Public International Law, Dashtestan Branch, Islamic Azad University, Dashtestan, Iran \\ Correspondence: Marjan Hossein Zadeh, Department of Private Law, Boushehr Branch, Islamic Azad University, \\ Boushehr, Iran. E-mail: marjanhossinzade@gmail.com
}

\author{
Received: February 14, 2016 Accepted: March 8, 2016 Online Published: March 31, 2016 \\ doi:10.5539/jpl.v9n2p154 \\ URL: http://dx.doi.org/10.5539/jpl.v9n2p154
}

\begin{abstract}
As a professional career, builders and building supervisors' activities is accepted as an especial liability from legislator's point of view and every especial liability has its own technical its bylaws, the building control engineering system and national building regulations were provided and ratified that are necessary for the sake of security and protection of the buildings and structures and they are essential as the most basic civil rights. With analysis of relevant laws and regulations we realize that builders and supervisors' responsibility is assumed as building fault-based liability by the legislator and liability without fault is an exception of the fault principle and the injured party to claim compensation of loss does not need to prove fault, so the builders and supervisors must take utmost caution in this regard. But about how, when and who they can plan their complaints, aside from the client, third parties such as buyers, passengers, entrants to the construction site and owner's adjacent can all sue against the above-mentioned persons and all of them are relatively liable for damages to life and property losses of injured persons.
\end{abstract}

Keywords: builders, supervisors, civil liability, criminal liability, disciplinary liability, loss compensation

\section{Introduction}

One of the specific responsibilities is the responsibility of builders and building supervisors. A construction is very important in all countries more or less and therefore following it there are diverse and certain rules and regulations. Characteristics of this type of construction and the need for stability, safety and security, has made force legislator on direct intervention and regulation on different aspects .Because of the need to ensure the quality of the building as one of the most fundamental rights of citizens, the protection of consumers and new buildings, structures are needed to obtain credible assurances from the manufacturers. Another important issue is monitoring on the building. According to the clear wording of Article 34 of the Statute engineering system and also in accordance with Clause 7 of Article 100 municipal construction supervising engineers have to monitor building operations that are built in charge of them, In terms of compliance of building with the specifications contained in the building permit and map continuously monitor and at the end certify matched building with permits, drawings and technical calculations. Engineer supervisor has agreed that such liability should be responsible for all technical matters. In such a case, the injury meant he was committing fraud and lack of oversight by government regulations. In such a case, the occurrence of event meant he was committing fraud and lack of oversight by government regulations. In connection with these discussions, liability is classified in two types, civil and criminal. This study deal with legal problem related to the subject that refers the laws, regulations and rights and part of the professional ethics.

\section{General}

\subsection{Engineer Supervisor}

Natural or legal person that has validate academic document(s) and professional qualification or certification of engineering consulting services controls on the implementation of construction work, including the method and quality of application and the materials used, according to the plans of adopted implementations and in adapt and comply with National Building Regulations and supplies of former planning and management organization and other protective and technical and security regulations. This monitoring can be described in terms of continuous 
(observer based) or describing periodic (supervision). If the violations of supervising engineers be in the field of engineering regulation systems and building control, proposed and handle in disciplinary Council of the province's Construction Engineering system and if the damage is caused by the engineer performance, it is verifiable accordance with the rules of civil liability in the courts of justice are competent (law of engineering system and building control)

Engineer supervisor and employer, as well as other contractual committed relies on Article 10 of the Civil Code have signed their contract with setting subject of contract and conditional provisions set forth in it . Basically supervision contract is to monitor the technical performance of building construction, is subject of building permit issued by municipalities and criteria for monitoring is plans that is available in case of the municipal building and approved by the municipality and, if needed, of course, has been reached to approve engineering organization. Engineer supervisor can't monitor on the technical performance of their building, which is executing the building and the observer cannot make any financial relationship with the owner or act in a way that has an interest in the project (Derived from Article 25 of the Regulations Article 33) monitors on the quality of the project in general, it depends on the person and supervisory engineer cannot assign it to another.

\subsection{Building Builder}

In general, is a natural or legal person having academic degrees and professional qualification (in the true premise) and contractor certification (in the legal presumption of) on plans of action adopted and in compliance with all implemented technical standards and regulations including issues of former management and planning organization and a national building regulations, has the duty of all construction operations. Title of manufacturer means the natural or legal person that is responsible for the construction of a residential unit in the private sector (private projects). Enforcement is as technical representative of owner in implementation of building and responsive to all regulatory process of action to supervisor and other authorities of building control. Since the field of inclusion of engineering regulation, building control, construction law and consequently national building regulations, also covers owners, So owners as a performer and building builder can assume all operational tasks of building construction on the condition that they act according to law engineering systems, and building control and be in charge of the all liability resulting it.

\subsection{Seizure of Building}

Means of the occupants of the building is one who dominates it, the current and material domination on the building not necessarily property, is building, So who seizure illegally, in which case it is known possessor and he is duty to protect its property. One of the obvious cases that the legislator in the Civil Code accepted liability arising from the objects is Article 333 of Civil Code the which states: "A wall or a building or plant owner is responsible for the damage that can be achieved its deterioration provided that the owner was aware damage has produced as a result of malfunction, or the lack of his care. Mean " the "owner" of the mentioned article, is wall or building owner of the plant or maximum who have been entrusted safety and preservation and protection of the institution to him.(Darbpour, 2011).

Transfer of ownership is not the reason of possession and the buyer until the delivery of the property, building or construction is not occupied as well as the vendor who sold the building but did not give the buyer, in fact, is the legal proprietor .

\subsection{Workshop of Building}

Inferred to the provisions of Article 4 of the work Law: The workshop is a place that worker is working at the request of the employer or his representative, such as industrial, mining, construction enterprises, trade, manufacturing services, public places and so on ...observance of safety principles and protection of construction site according to the law of engineering system and building control is designed by executive of manufacturer or engineer and in case of any damage caused by construction sites, he is responsible for it. (Executive Regulations of Engineering system)

\section{Duties and Obligations}

\subsection{Duties and Obligations of Manufacturer}

3.1.1 Manufacturer Duties and Responsibilities to Protect of the Construction Site and Responsibility Resulted from It

Article 12 of the Executive Regulations of the engineering system law and building control provides: "regard of safety principles and workshop protection and environmental issues are the responsibility of the executive". Therefore, the duty of workshop protection is in charge of manufacturer personally and any losses is created 
resulting from non-compliance with conservation tips, he is sponsor and must provide compensation. But on what time and for how long this will be the task of the manufacturer? Looking to paragraph A of Article 21 of the General Conditions Agreement which states: "The contractor (builder) from the day of workshop delivery to the day of temporary delivery of contract issue operations is responsible for the maintenance of work done, materials, machinery and tools, fields, staircase, facilities and buildings that are under his care and view, and for this purpose he take necessary actions for its maintenance and protection into the workplace against atmospheric agents and ensure water and theft and fire, and so on. ", So we see clearly the answer to question in this article .builder legally occupied building or construction site in this time (Ddarabpour, 2006).

In Iran law, violation of the rights of homes and the properties is a criminal offense and legal defense against such acts is not crime and consider of the causes of crime, provided that defender observe the defense conditions in espect, both criminal and civil responsibility is canceled of the assailant (Zeraat, 2013).

The new Islamic Penal Code in Clause 2, Article 156 has expressed ruling a form of legal defense issue. in this way that That if principle of self-defense proved to assume the defense of the assailant has not been met. Clause 2, Article 302 of the Penal Code also defines substantive ruling: ( $\mathrm{f}$ proven, the defense committed a crime in the state but does not meet the requirements of self-defense is a deliberate act like he is. So for example, if the proprietor of the earlier obstacles such as glass or current-carrying wire placed at the entrance as if someone tried to rape or intrusion to have the building, thereby causing harm to him and his arrival be, self-defense does not apply in these cases And exceed the requirements of self-defense is clear and committed the crime intentionally is deliberate But if the risk is or is invaded and occupied the position of self-defense and the defense of their jurisdiction, but the defender has his practice, often be mistaken for For example, a person who had raped someone else in darkness and target rather than rapist or a device that is used for defense, does not fit with risk. Defense of his responsibility for the crime of inadvertent errors that cannot be ruled out. According to Clause 2, Article 302 IPC and committed to pay compensation and punish but the fact that non of rape and theft, such as fire, water confidence and general conditions in Article 21 of the Treaty expression and protection of the workshop is not constructive. Looking at the paragraph of the article which states: " Looking at the paragraph of the article which states: "The contractor is required that all buildings and temporary facilities, machinery and tools shop that belonged to him or at his disposal and for operations subject to the treaty, the cost of insurance and the employer to submit copies of insurance. Machinery and equipment, the employer (client) with the contractor, the employer's insurance. "It can be inferred from the fact that the manufacturer is obliged to insure the items listed, so any damage that in this way the client is found, the manufacturer will be responsible and liable for compensation, Unless your employer is obliged to insure them.

3.1.2 Duties of the Manufacturer to Comply with Technical and Health Protection Guidelines In accordance with Paragraph B of Article 21 of the General Conditions pact that poetry is: Contractor technical and health protection regulations, and guidelines, are responsible for damage to a third party in the courtyard of the workshop and in any case, the employer has no obligation in this case. If the employer and the consultant can non-compliance with technical and health protection guidelines, to stop part of the work which is necessary to establish safety guidelines mentioned safety issue. "The main clause of Article 21 of the Treaty on the basis of general conditions, as the proprietor is the manufacturer It is assumed that there is a risk of the occupants in the property (building site) Get to prevent harm to others and must make decisions that may have negative or positive action is, As a result, it becomes clear that the decision of the recklessness or negligence have taken place or not? Amendment to Article 145 of the Penal Code, also the fault of negligence and recklessness and negligence whether and knows. That carelessness and recklessness of positive action measures is negative. The rights of the Paragraph 1 of article $508 \mathrm{BC}$. M.a according to the manufacturer should be allowed to engage people with their actions they warn warning and notify them of the danger. The human task is observed that the illegal entrants or coercion or by mistake or for any other reason have to enter the property as a result of risks, damage has been inflicted upon them, are responsible. However, it seems important that the warning notice must be reasonable. Usually barrier around the construction site, install signs and signals danger and risk warning given by the entrants. If the manufacturer or possess sufficient and effective measures and entering of injury, the manufacturer will be absolved of responsibility. Article 523 of the Penal Code does not apply in this case. But should the physical condition, age and incoming considered For example, if a child or a person blind or illiterate, the alerts and warnings to prevent people from entering the workshop and the effect on risk, not into the workshop and are damaged, and have damage to make up for Building Manufacturer sponsor. So if the manufacturer effective and adequate warnings be given fault is damaged But according to legislative policy in support of the injured and extreme caution on the part of the holders of professional careers and are dangerous, damaged only the design but the criminal case denied civil liability and insurance litigation is able to plan . And 
the absolute liability cases or upon the Iranian legal system has been accepted. Paragraph (f) of Article 21 of the General Conditions of the Treaty provides: "The contractor is committed to your operations so do the appropriate transit and roadway pavements for pedestrians and vehicle traffic always stay open And its materials storage sites that cause discomfort or inconvenience residents or bystanders is not around The use of machines and tools in normal working hours, and the resulting sound, as well as use of specific ways to perform the operation does not constitute a nuisance.. In cases where the execution of the work require that part of the roadway or sidewalk for a temporary period to inform the consulting engineer or engineer supervisor is completely blocked, The contractor has the necessary authorization from the local authorities, traffic diversion by way of the path it must be approved by the consultant engineer, supply. Employers also need assistance to study the required permissions to operate. The laws also in this case can be of 331 and 330 BC. M.a noted. Article 331 and it works with the most common fault information: "Everyone in the place that they may not stop at the stop or object or device based on such sites, and one mistake and without the intention of the person or object or device do not hit the die (bears injuries or be) Person stops or who object made by those in charge of the money will be deployed And also, if you stop the person or object the establishment and the means to slip through and damage the person responsible for the payment of blood money, damage or injury, and Article 330 AH .m.a expression versa (penalty) provides: If someone on your property or place and way to stop it is permitted to be parked or stopped vehicle and hit him and injured another stop that person is responsible for not any damages.

\subsubsection{Manufacturer Tasks Concerning the Protection of Infrastructure, Buildings and Liability Arising from It}

The manufacturer shall building operations (contract) to be run on the workshop facilities, such as water lines, electricity, gas, telecommunications and harm. If the action is damage valuable facilities listed manufacturer is committed to its cost to fix the damage and restoring them to take action If the manufacturer or negligence and failure to fix the damage and immediate action not taken, the employer (client) can be any expedient way to know for remedial action And in accordance with paragraph (h) of Article 21 and 23 of the General Conditions of the client contract can be toward the restoration and remedial action taken and the costs and damage, plus $15 \%$ to account for the demands of the manufacturer's debt deduct. In this case, the manufacturer will have no right to protest. It can be concluded from the material in the documents relating to the construction of the building should be marked with all drawings and specifications and instructions and the manufacturer must determine their status from the consulting engineer Inquiry and then with consulting engineers, for drilling operations to take action. In this case, if an accident occurs and the damage, the manufacturer based on the type, the location or the facility in accordance with the contract documents and has been approved by the consultant engineer will be absolved of any responsibility. If you need to change the status of implementation of building infrastructure facilities can host a manufacturer or engineer to client information to relevant organizations for changing the act and costs arising from it is the responsibility of the employer and the employer's costs related to the changes. Therefore it can be concluded that the responsibility of the manufacturer's regulations against negligence and irresponsibility (fault and mistake), is a contract liability.

\subsubsection{Responsibility for the Damage and Bodily Injury Caused by Error Builders Professional}

The manufacturer is obligated under the contract to build a building without flaws, but unfortunately the injury and damage caused to illustrate the lack of commitment to be desired and because of the skill and technical knowledge on such damages typically predictable. But regulatory time limit is considered to be over 10 years can claim compensation plan and to demand action And the fault of the manufacturer in this regard given the need to prove the fault of the injured party does not exist but the manufacturer can prove their responsibility to fix the external cause. As for the physical injuries that are considered to be moral damages, the French civil code does not refer to the loss of spiritual and moral compensation in the country due to judicial procedure. And any objection to compensate spiritual and accepted the General Board of the Supreme Court decision in June 1833, no doubt, knows the irreparable moral damage (Jourden,Patrice, principles of civil liability, the translation by Adib, Majid,Printing Mizan Publication, 2012, 3 Edition ,p189) .

Producer responsibility, responsibility is clear and predictable rule of the damage criterion in practice because every manufacturer knows that whenever typically do not work safety and the technical principles, it may be lives and property of those provide risks, Therefore, pursuant to Articles 1 and 2 Direct Tax Act and Article 14 of the new .d.k If this task does not respect the law and necessary precautions to ignore the violation of his constitutional duties And in the event of an accident and cause bodily injury to persons, disadvantaged on the basis of legal liability, tort can fight against the project builder.

\subsubsection{Producer Responsibility for Building the Second-Hand Buyers}

In Iranian law, regulation explicitly about second-hand buyers do not exist, but according to Article 231 of the 
Civil Code, which states: 'Transactions and legal contracts, just about the bargain and it is effective surrogate: The next buyers are owner and vice president of legal Can damage buildings, according to the contract are also common elements of civil liability, the proof of harm caused to consumers due to the negative and positive actions (negligence and recklessness) manufacturers of the responsibility for losses incurred body against unconventional manufacturers design their fights. And also the engineering system based on Article 18 of the Regulations, which provides: The presenter is obliged to ensure the implementation of quality construction that makes our responsibility, based on guidelines issued by the Department of Housing and Urban Development act And where quality assurance is required to provide insurance, insurance for the benefit of the owner and subsequent owners will be prepared and presented to them. After the material is such that the creators of the acquired second hand buyers responsibility. In accordance with a quality assurance structure, the responsibility for builders, there are ten years old. According to a guarantee if, after ten years of physical loss or damage caused by errors by operators to enter the building owners, the possibility of project, there is no case against the builders. But lawmakers' liability under Article 493 of the Penal Code on the grounds expressly states: The gap of time between the perpetrator and the result of it is not prevented from investigating crimes such as death resulting from transmission of the deadly disease that caused the death or atonement is the case. The gap of time between the perpetrator and the result of it is not prevented from investigating crimes such as death resulting from transmission of the deadly disease that caused the death or atonement is the case. This provision of article (492) of the Act applies to all current crimes ". After it is inferred that if carelessness or recklessness manufacturer, decrease the quality of the building and thus incident occurred and in this way to someone is hurt, Can be filed based on the raw material manufacturer is the subject of a quality assurance building does not conform to this matter.

\subsubsection{Builders Liability Arising from Actions of Employees and Workers}

In Iranian law, Article 12 of the law of civil liability to be understood that the legislator employer because of the damage that his workers have entered the third parties responsible are brought. To fulfill this responsibility, there are necessary elements: labor relationship, labor and harmful act prejudicing the work or its relevance. Employer's liability and fault-based liability is assumed legislative and regulatory policies to support the disadvantaged And some believe that the stronger employer of labor and a greater ability to compensate, or to target law to workers' insurance, employer responsibility lay. But first consider more closely the purpose of Article 12 of the Direct Tax Act, as mentioned in the following article, possible responsibility of the employer to prove the fault of the worker is predicted.

\section{The Duties of Supervisor Engineers}

The duties of construction supervisor engineers can be found in different Articles including: the law of engineering system and construction controlling and its executive bylaw, Article 9 and 33 of general conditions of contract, Note 7 of Article 100 of the municipal Act.

A supervisor engineer undertakes contractual and legal duties, based on supervising services or technical services contract with he must sign with a client or building owner in compliance with Article 10 of the Law. It should be noted that the commitment of supervisor engineer is as commitment of constructor, meaning that the supervisor engineer is committed to obtain the final result of his job that is supervision and continuous quality control on the construction of the entire building. Article 100 of the municipal law obliges the owners of lands and properties located inside cities or in the suburbs to receive construction license from the municipality before performing any civil action or land separation and before beginning the construction process. According to Article 24 of the executive regulations of the law of engineering system and construction controlling, during issuing the construction license, a supervisor engineer will be selected by the provincial civil engineering and he will be introduced to the owner and to authorities who are in charge of issuing the license. In addition, it explicitly expresses that the supervisor should not work in the agency that is responsible for issuing the license in that area. Note 2 of this Article indicates: Instructions about the mechanism of work reference, supervision, the amount of payment and its receiving and paying procedure and also resolving disputes between supervisor and the executor will be prepared and communicated by the Department of Housing and Urban Development.

\subsection{The Duties of Supervisor Engineers in Recognition of Possible Problems and Warning Beneficiaries}

Experts, because of their knowledge and expertise, the society expects them to pay more attention to subtle and special scientific issues; Because ignoring any of those issues, may create accidents and dangers in buildings and may lead to irreparable financial losses and human casualties. The supervisor engineer must monitor all the responsibilities of a constructor in the process of constructing a building and in the case of recognizing problems and potential hazards, he must warn the client and other beneficiaries, including contractors and nearby residents; 
otherwise, the supervisor has failed to perform his legal and contractual duty, that is observance of the principle of caution and care and therefore he is responsible for compensation.

Supervisor engineer also has a professional civil liability and in the case of damage caused by his act, he is guilty of professional negligence. According to the proposed bill entitled 'constructors and quality of buildings insurance' which was submitted to the parliament by Ministry of Housing and Urban Development; but unfortunately is has not yet been passed (Article 3); the constructor can request the supervisor engineer for their liability insurance in the benefit of the constructor and in the case of imposing damage, the insurer will compensate for that damage. If the constructor refuses to request, indeed he has harmed himself because the constructor is principally responsible for construction and he is responsible for damages resulting from the defects of the building. Passing this bill will result in further clarification of responsibilities in this arena.

\subsection{Commitment of Supervisor Engineer in Monitoring Employment of Expert Human Resources and Subsequent} Civil Liability

Paragraph (i) of Article 17 of the general conditions of the contract states: "In the implementation of this convention (construction) the contractor is responsible for the actions of his employees; if the personnel and workers of the contractor and subcontractors are not qualified to perform their relevant jobs or if they disturb the workshop, at first the consulting engineer or the supervisor engineer will notify the head of the workshop and in case of repetition he can ask the contractor to dismiss the violators. In this case the contractor is obliged to execute the command and he cannot employ dismissed workers to work in that workshop. Implementation of this command does not reduce contractor's liability and does not create any right for him". In the event of damage caused by employing unskilled workforce in the construction process, the affected person can complain against the supervisor engineer, because of his negligence in monitoring employing skilled workforce and because he has not warned the constructor in employment of such a workforce. The supervisor engineer can extricate himself from this liability by presenting evidence of written warning to the constructor and evidence of announcing violation to licensing authorities. But if the supervisor engineer fails on proving his reasons, according to Article 1 of the law he will be responsible along with the constructor.

\subsection{Commitment of Supervisor Engineer in Monitoring Application of Normal and Standards Materials and Subsequent Civil Liability}

Investigating the quality of materials is one of the legal duties of supervisor and civil engineer and he should not fully trust to supplier in this case; but if the client provide materials himself, then the supervisor engineer won't be responsible for their low quality; but he must warn the client and the relevant authorities by writing a warning; meaning that, whenever during the executive operations the supervisor engineer or the executor, notices defects in construction materials and does not mntion it to the client, he has not fully performed his duty(Bagherniyaye hemmati, 2011).

From the concepts derived from paragraph (D) of Article 33 of the general conditions of the contract and Article 1 of the law, we understand that in this case if the supervisor engineer commits some negligence and this negligence impose a damage to a person or the building, then according to the causality rule, the supervisor engineer will be responsible for compensation.

\subsection{Violations of Supervisor Engineer and Subsequent Civil Liability}

Article 91 of the law of engineering system and construction controlling has generally indicated disciplinary and vocational violations of construction engineers and in Article 90 of the above law, punitive punishments have been specified. Article 91 of the law stipulates that: disciplinary and vocational violation includes violating some affairs that their performance is necessary due to occupational license subject to the law of membership in the provincial civil engineering.

Violations of any members of a community or association, in relation to their reputation and career and their vocational and administrative duties should be judged in terms of their importance and therefore they require different reactions; so committing a vocational violation will lead to punitive liability what is called occupational, corporate, vocational or punitive liability or liability arising from punitive violation; such as liability of lawyers in defending lawsuits or liability of doctors in treatment and surgery or liability of construction engineers in construction proce?(Hodavand, 2011).

If the supervisor engineer immediately report the violation which has been committed in constructing the building to the authorities who are in charge of issuing the license, his civil liability will end at this stage. After this report, the civil liability of that stage of construction will be transferred to the authorities issuing the license and after recording the violation report liability of supervisor engineer will be suspended until announcement of 
removal of violation and issuing written permission by authorities for continuing construction. During this time, the supervisor engineer will have no civil or punitive liability for unauthorized construction of building. These issues can be considered as rejection of lawsuit by affected to request compensation from supervisor engineer.

\subsection{Intentional Violations by Supervisor Engineer and Subsequent Punitive Punishments}

From the perspective of legislator, as professional services have such importance and impact that the slightest negligence to them may lead to accident and may jeopardize the safety of operator; therefore a professional expert by understanding this issue must perform his duties in a way that his professional services never impose any harm to the others and otherwise, it implies that the person has not completely followed his professional principles and duties and this is called professional mistake and in this case the punishment will be determined based on the impact of committed mistake. In professional careers, accident occurrence and imposing financial damages and deaths in addition to punitive aspects can have civil and criminal aspects, as well. Punitive liability is the result of violation of specific social rules and has its own enforcement guarantees, including suspension from duty and revocation of employment license. These punitive punishments will be considered because the person has conducted some action in contrary to his duties and his occupational status; but its civil aspect is to compensate for financial damage which has been imposed to the person and its criminal aspect is in order to protect public rights (Ardabili, 2008).

Although, according to Article 145 of the Law and its following amendment, special liability is considered as an unintentional crime, however intentionally of such violations is important in enforcement of punitive punishments.

\subsection{Unintentional Violations by Supervisor Engineer and Subsequent Punitive Punishments}

According to the explicit text of the Act (Note 7 of Article 100 of municipal Law) Supervisor engineers are only required to provide a maximum of two kinds of reports: 1 . Termination of construction license 2 violation occurrence (if the client or the constructor commit a violation). However it is strongly recommended that supervisor engineers must immediately report the slightest failure committed by client or constructor in each case to the competent authorities and receive the receipt or its record number. Also, whenever they observe any violation, in terms of non-compliance with safety and technical regulations or non-compliance of constructive operations with the maps and contents of the license, in the first place, they must inform the project manager or the owner and in the next step, he must report the violations along with the reasons to the municipality. Otherwise, he has committed a professional mistake and negligence and has not fully performed his legal duty that is caution and taking care. According to the Iranian laws, vocational negligence resulting from non-compliance with governmental regulations or lack of skill is considered as realization of unintentional crimes. Even if as a result of committing vocational negligence, an accident occurs and results in death of a person, it will be considered as unintentional homicide. The legislator in addition to Article 145 and Article 1, in Article 616 of the Law stipulates that: "If a person commits an unintentional homicide, due to the his negligence or recklessness or attempting to commit something that he is not skilled at it or because of non-compliance with regulations; that person will be condemned to one to three years of imprisonment and to pay blood money in the case of demand by victim's family, except for cases in which the mistake is obvious".

The role of supervisor engineers does not seem to less important compared with that's of constructors in creating dangers and accidents, because although the constructors are direct actors and executors, but supervisor engineers, with neglecting and ignoring these violations, facilitate committing these violations and neglecting safety and technical regulations and they are considered as the perpetrators in this regard. According to the Islamic Penal Code we cannot consider the constructor and the supervisor as partners in committing unintentional crime and condemn them to pay the blood money; because in the Islamic Penal Code, assumption of participation in quasi-intentional crimes and obvious mistakes which is subject to paying blood money is not easily perceivable; but it is possible in the case of Taaziri punishment; but according to Article 616 of the law, the legislature has only determined criminal liability for the events which lead to death (not property damage or physical injup63)( Hodavand et al. 2011).

\section{Conclusion}

By peer deliberation in issues discussed in this article we conclude that the liability of constructors and supervisors, with specific regulations in this area will be determined as special liabilities and their general liability as a member of the community will be determined according to the general rules of civil liabilities and general rules of contracts. In the case of imposing damages and injuries, the owner and the client and their deputies, such as the purchaser or the purchasers, can claim for compensation in the case of violating the contract and even violation of commitments which have not been specified in the contract, but they are considered to be 
related to the contract by society and they are limited to building damages. In fact, any violation of commitments and duties or in other words, lack of proper implementation of building operations, reveals constructor's fault; because since these are some technical and specialized professional occupations, the legislator considers these violators to be guilty.

During the executive operations, sometimes some accidents occur and in that case the constructors, as the technical representative of the owner and the supervisor, as representative of supervision on strict implementation of the regulations are responsible for any damage. It is the responsibility of the supervisor to monitor and supervise all the legal and contractual duties and commitments of the constructor for the client and for third parties. The responsibility of constructor in protecting the workshop includes conducting some activities such as; warning, safety and security measures, occupational health, machinery maintenance and according to the law of engineering system and construction controlling and also based on civil law, it is the responsibility of constructor as the legal possessor. Also using construction materials and employing skilled workforce are among the legal and contractual obligations of constructor, in accordance with the provisions of the contract and based on the common law; but supervisors in the case of observing any violation of relevant regulations, which represent recklessness and negligence by constructor, must perform their legal duty by warning him and reporting the violation to the authorities; otherwise, supervisors have facilitated committing the violation, by ignoring it and therefore they have imposed losses and damages to the client and to the third parties. In this case, supervisors have also committed a professional fault and in the case of creating damage, like constructors, in addition to punitive liability, they have civil and criminal liabilities as well.

Since, any violation of construction rules and regulations will lead to some predictable consequences, so in these cases the employer's liability is fault-based liability. Even when the constructor follows all the rules and principles, but an accidents or damage is caused by worker's action, with reviewing and deliberating in Article 12 of the Civil Liability Act, we find that again employer's liability is based on his fault; because the legislator has allowed him to prove his innocence and prove worker's fault and demand the worker to pay the compensation. In cases which the constructor conducts all necessary, adequate and effective measures in order to alert and warn people, in construction site and dangerous environment, but unfortunately due to his activities someone incurs a damage or injury, although the constructor will be exempt from criminal liability, but his civil liability will still remain; so it is clear that this liability is unintentional liability in this regard and this legislative policy aims to support the injured party.

About the scope of responsibility of constructor and supervisors, since, according to Article 18 of the regulations of the law of engineering system and construction controlling, constructors are required to provide a building quality guarantee and also Article 30 of the Fourth Law of Budget and Planning has obliged licensing authorities to provide a building quality guarantee for owners to hand it to purchasers and operators and on the other hand, this law obliges insurance companies to provide 10 year insurance policy, so constructors are responsible for damages for ten years from the time of constructing the buildings and transferring it to the owner. However, experts have determined building's useful lifetime to be 40 years and this is contrary to the 10 year insurance policy; but supervisors due to their duties according to the law of engineering system and construction controlling and amendment 07 of Article 100 of municipal law, their liability is limited to reporting basic stages and announcing the violation to the authorities and after announcing the violation, he can continue his supervising work, if that authority issued a written permission and announced resolving the violation; so supervisor engineer, can extricate himself from any responsibility by reporting violations; so in fact, according to specific regulations the responsibility of constructors is limited to the time of insurance policy that is ten years; while, according to Article 493 the Islamic Penal Code, existence of time interval between committing the act and occurring the damage (physical damage) is not an obstacle to the realization of the crime.

When, in creating damage, two (or more) people are involved, only these two people will be responsible for compensation and the court will refer the case to an expert and it will determine the amount of guilt of the perpetrators which are constructor and supervisor in this case and therefore dividing responsibilities is relatively accepted. According to specific regulations, the main responsibility rests on constructors, but in most of those cases in which the constructor and the supervisor are both faulty, in verdicts issued by the judicial authorities the maximum liability has been considered for supervisors. It seems that the aim of appointing the supervisor engineer in this domain is to ensure the implementation of construction principles and preventing any violation, so this duty is more important and sensitive; while in accordance with the regulations, primary responsibility in occurring damages rests on constructors, so this is clearly contrary to the provisions of the jurisprudence, in Iranian law.

It should be noted that according to Article 616 of Islamic Penal Law, Taaziri punishment will be determined 
only for those crimes which have resulted in death of somebody (fatal accidents) and paying blood money to injured party which has been provided in the panel code, is one of the examples of civil liability based on Article 1 of this law and criminal liability for constructors and supervisors, is limited to fatal accidents.

\section{References}

Ardebili, M. (2008). General Criminal Law (Vol. II). Printing Mizan Publicationp.

Bafande, A. (2010). The builders and contractors responsible for building structures in the country according to existing rules for staff, clients and third parties, PNU Tehran Central Branch, p136-146, p 114-196.

Bagherniyaye Hemat, M. (2011). civil liability of the contractor and engineer, construction supervisor, Gilan University (Campus International), p70-103.

Darabpour, M. (2006). civil liability arising from property damage, structures and buildings (comparative study with English law), Legal Research, No. 44, p143-165.

Darabpour, M. (2011). responsibilities outside contract. printing Majd publication. p 160-164.

Ghasem Zadeh, S. M. (2010). the law of contracts and obligations,printing dadgostar, 14 edition. p 223-294.

Ghorbanpoor, A. (2006). causal system of civil liability, the legal journal of Justice, No 54. p 18.

Hodavand, M., \& Ahmadi, M. (2011). the legal system to deal with violations of Engineers building, printing Jungle publication, p 50- 65 .

Hosseininejad, H. (2010). civil liability (new edition). printing Majd publication, p 23-87.

Jourden, P. (2012). principles of civil liability, the translation by Adib, Majid, printing Mizan Publication, 3 Edition. p 40-143, p160-189.

Katozian, N. (2007). new values and changes in civil liability, judgment magazine, No. 44, p 8.129.177.

Katozian, N. (2008). general rules of contracts, Printing Inc. publication, Volume IV, 15 edition. p 116-211.

Rah pyek, H. (2013). a civil liability law and compensations (new edition). printing Khorsandi publication. $\mathrm{p}$ 7-14, p 50-65.

Rezai Roodsari, H. (2002). civic responsibility, building supervisor, University of Qom, p 81-209.

Sadeghi, M. (2014). comparative study contract manufacturing order in jurisprudence, printing Khorsand publication, p197-312.

Sadeghi, M. H. (2010). specific criminal law (crimes against persons) (Vol. I, 19th ed.). printing Mizan Publication, P 199-249.

Samadie Qushchi, Z. (2013). building violations in the Iranian legal system, printing Jungle publication, 6 Edition. p 306-329.

Zeraat, A. (2013). the general criminal law (Volume I II, 2 ed.). printing Jungle publication. p 118-125.

\section{Copyrights}

Copyright for this article is retained by the author(s), with first publication rights granted to the journal.

This is an open-access article distributed under the terms and conditions of the Creative Commons Attribution license (http://creativecommons.org/licenses/by/3.0/). 